\title{
Investment Priorities of the National Economy Sectors Development
}

\author{
Valentyna Stadnyk \\ Department of Management, \\ of Administration and Hotel \\ and Restaurant Business, \\ Khmelnitskyi National University, \\ Khmelnitskyi, Ukraine \\ stadnyk v v@ukr.net \\ http://orsid.org/0000-0002-2095-3517 \\ Tetjana Tomalja \\ Department of Management, \\ of Administration and Hotel \\ and Restaurant Business, \\ Khmelnitskyi National University, \\ Khmelnitskyi, Ukraine \\ sts8383@ukr.net
}

\author{
Pavlo Izhevskiy \\ Department of Finance, \\ Banking and Insurance, \\ Khmelnitskyi National University, \\ Khmelnitskyi, Ukraine \\ zhevskypavlo@gmail.com
}

\author{
Nila Khrushch \\ Department of Finances, \\ Banking and Insurance, \\ Khmelnitskyi National University, \\ Khmelnitskyi, Ukraine \\ nila.ukr@gmail.com \\ http://orsid.org/0000-0002-9930-7023
}

\begin{abstract}
The problem of determining the investment priorities of the national economy development has been actuated. It has been argued that the formation of institutional preferences for activation of industry investment processes should be carried out taking into account the potential ability of each sectoral group enterprises to increase the added value. The scientific and methodical approach for sub-sectors investment attractiveness assessment has been formed on the example of the Ukrainian food industry. It has been recommended to use for this substantiated set of relative performance indexes which are duplicated in aggregate statistical state surveys based on the enterprises financial statements. It has been formed the recommendations for the investment priorities of food industry development in Ukraine which are based on the appropriate calculations made by the TOPSIS and CRITIC methods.
\end{abstract}

Keywords - investment priorities, food industry, TOPSIS method, CRITIC method, cluster analysis, national economy.

\section{INTRODUCTION}

Ensuring sustainable and dynamic development of the country is a key task of the economic policy of each state. This policy is developed taking into account existing and future social (including global) needs and the ability of national economic entities to meet them, relying on their (specific for each) competitive advantages and opportunities for their build-up. The presence of a significant number of such entities in certain industries determines the country's place in the world division of labor. Quite a lot of countries use their natural resources to create competitive advantages, which can be unique and have value in the world market, even with a minimal degree of their processing. However, history shows that such countries, which mostly offer raw materials for the exchange on the world markets, are increasingly lagging over time behind in the level of economic dynamics and quality of life of the population from other countries that develop their ability to create new consumer values.
The formation of such ability is of paramount importance to Ukraine, because the national economy in the world division of labor still occupies the position of raw material supplement to the economies of the developed countries. However, the current stage of its development is characterized by a change in the vectors and priorities of economic cooperation due to European integration processes. It is important that, in the course of these changes, the Ukrainian economy could take the best positions in the global market from the standpoint of macroeconomic perspectives. This requires a sound approach to determining the directions of structural changes and their implementation through appropriate investment processes, supported at the institutional level through the tools of state economic policy.

Many researchers deal with the problem of the formation and implementation of an effective state economic policy in different market contexts. In particular, in Ukraine, this problem was reflected in the works of D. Lukianenko, A. Poruchnyk, V. Kolesov [1], O. Bavyko and M. Petrenko [2], S. Radziyevska [3], V. Reshetylo and I. Ostrovskyi [4] and many others. The authors express different views about the instruments and directions of institutional support for the development of the national economy, but it is indisputable that it should ensure the growth of its international competitiveness.

A special interest in this problem arose in recent years, as the crisis phenomena were the reason for that in the socioeconomic processes of many developed countries, whose governments supported the dominance of market mechanisms of macroeconomic regulation. Ideally, these mechanisms should ensure capital inflows (inflows of investments) into those sectors of the economy in which greater added value is created, that would ensure the conditions for sustainable socio-economic growth. In particular, this was referred to in the UN Recommendations for those countries (2013) for post-2015 development, which justified the need to transform economies in favor of 
employment and overall growth based on value added and productivity through industrialization as the central strategy for achieving this transformation [5].

However, M. Olson once emphasized that, with strong lobbying, "the choice of state support sectors can create preferences not to those who could use them most effectively from the point of view of the interests of the country" [6]. It can be confirmed by the fact that quite often unjustified preferences were received by individual economic entities in Ukraine at different periods of market transformation. Proceeding from the current political and economic realities in Ukraine, it is important to more reasonably approach the definition of the directions for the formation of such preferences from the point of view of improving the dynamics of overall economic growth.

Indicating the decisive role of the state in regulating economic processes, J.I. Lin focuses on the strategic use of limited resources of the state for the targeted support of certain industries in which a comparative advantage is probable [7]. In this, his position coincides with the position of M. Porter, who highlighted the directions for the formation of these comparative advantages in the context of the national economy (so-called "diamond of competitiveness") [8]. In its composition, the opportunities of the industrial sector, which in different countries have their structural completeness, take on the prominent place. But most of all it creates the largest number of jobs in it and accumulates the largest share of value added.

Supporting the necessity of developing the industrial sector in each country, J. Stiglitz and J. I. Lin noted that "specific political levers and the institutional framework for generating of optimal industrial policy results" should be defined in appropriate contexts [9, p. 9]. Depending on the tasks to be solved in the course of structural changes in the national economy, as well as on the institutional characteristics of the economic environment, different forces and vectors of leverage should be chosen that will form the economic basis of the regulatory mechanism. In our opinion, the vectors and levers of influence should deal primarily with investment processes and form from the standpoint of the value of investments in certain areas of economic activity for the national economy as a whole.

The purpose of the paper is to determine the investment priorities of structural and technological changes in the Ukrainian economy in the context of the implementation of the sustainable development concept.

\section{RESEARCH METHODOLOGY}

By the methods of logical analysis it has been argued the need of investment priorities argumentation of the national economy development according to the industry-specific based on synthetic indexes which are characterize the financial and economic dynamics of the industry enterprises in terms of their components of liquidity, debt management, productivity, profitability and changes in sales volumes and added value.

The method TOPSIS (Technique for Order Preference by Similarity to an Ideal Solution) has been used for determination the relative deviation from the benchmark by the groups of synthetic indexes of food industry enterprises activity from different sub-sectors. The weighting coefficients of group indexes were determined using the CRITIC (Criteria Importance Through Intercriteria Correlation) method.

\section{RESULTS}

The great amount of losses of national economies from the permanent world financial and economic crises and the further aggravation of geo-economic contradictions between countries of the world economy for markets and resources forced to raise again the question of the effectiveness of market mechanisms for ensuring the competitiveness and sustainable development of the national economy as a coherent economic system. Unfortunately, the realities are that national interests are increasingly giving way to the interests of global economic players, which are powerful multinational companies. This confirms the thesis of I. Wallerstein that the development of the global economy is most likely to take place according to the scenario of "fake transformation, superficial transformation" of national economies, whose purpose is "the inviolability of the existing inequality" in the global economic space, because this is in line with interests of the world economy leaders [10, p. 45].

In Ukraine, structural processes in the economy also develop according to the scenario of "fake transformation" in the interests of global economic players. They are interested primarily in expanding its resource base and markets. The main scopes of direct foreign investment are directed in the relevant industries. According to our calculations (made on the basis of official statistics), in the last 5 years only 6-7\% of the total volume of capital investments is directed into the machine-building industry, which among other industrial sectors should be able to create the largest volumes of value added. In the food industry, which increases the degree of processing of agricultural raw materials (creates value added within Ukraine) it is only $15-17 \%[11 ; 12]$

It should be emphasized that the development of the food industry should be one of the priorities in Ukraine. Being equipped with the latest technology, it will be the leading link in the chain of creation of consumer values, increasing the value added in the processing of agricultural raw materials of domestic origin. Processing enterprises of the food industry can combine the economic entities of the national economy involved in the whole process of food production in the interval "from raw materials to the final consumer". As the main integrators of the promotion of products to the foreign market, they will contribute to an increase in domestic commodity circulation in Ukrainian agriculture and an increase in external demand for highquality food products.

Obviously, in order to ensure sustainable economic dynamism, Ukraine must develop its industrial sector by creating new jobs with attractive working conditions. However, the formation of institutional preferences for activating investment processes in industry should be made taking into account the potential ability of enterprises of each branch group to increase the value added, and also to be competitive in the strategic perspective. Including, due to cross-sectoral integration processes, as shown by us in previous researches [13]. 
Therefore, the determination of the priority and investment attractiveness of the national economy sectors is possible only with the determination of their dynamics and developmental capacity, which is determined by a number of relative performance indicators in international business practice and is duplicated in aggregate statistical state surveys based on the financial statements of enterprises grouped according to sectoral characteristics and value added. The grouping and the procedure for calculating these indicators are given in Table 1.

TABLE I. INDICATORS OF EVALUATION OF ECONOMIC AND FINANCIAL SITUATION

\begin{tabular}{|c|c|}
\hline Indicator & Calculation procedure \\
\hline \multicolumn{2}{|c|}{ Group of financial liquidity } \\
\hline Current liquidity & Current assets / current liabilities \\
\hline Instant liquidity & $\begin{array}{c}\text { [Current assets - stocks - accrual] / } \\
\text { current liabilities }\end{array}$ \\
\hline Cash flow & $\begin{array}{c}\text { Short-term investments / Current } \\
\text { liabilities }\end{array}$ \\
\hline \multicolumn{2}{|c|}{ Debt burden and the ability to service it } \\
\hline Total debt obligation & $\begin{array}{c}\text { Commitments and provisions for } \\
\text { liabilities / assets }\end{array}$ \\
\hline $\begin{array}{l}\text { Commitment by tangible } \\
\text { assets }\end{array}$ & Fixed assets / long-term liabilities \\
\hline $\begin{array}{l}\text { Coverage of liabilities with } \\
\text { financial surplus }\end{array}$ & $\begin{array}{c}\text { [Operating profit }+ \text { depreciation] / total } \\
\text { liabilities }\end{array}$ \\
\hline $\begin{array}{l}\text { Coverage of interest with } \\
\text { operating profit }\end{array}$ & Operating profit / interest \\
\hline \multicolumn{2}{|r|}{ Productivity } \\
\hline Total turnover of assets & Revenue / asset summary \\
\hline $\begin{array}{c}\text { Productivity of operating } \\
\text { assets }\end{array}$ & Gross value added / operational assets \\
\hline Productivity of fixed assets & Gross value added / fixed assets \\
\hline Labor efficiency & $\begin{array}{l}\text { Gross value added / number of } \\
\text { employees }\end{array}$ \\
\hline Cost Index & Operating expenses / operating income \\
\hline \multicolumn{2}{|r|}{ Profitability } \\
\hline Operational & $\begin{array}{l}\text { Operating profit } \times 100 / \text { operating } \\
\text { income }\end{array}$ \\
\hline Operating assets & $\begin{array}{c}\text { [Operating profit }+ \text { depreciation] } \times 100 / \\
\text { operating assets }\end{array}$ \\
\hline Invested capital & Operating profit $\times 100 /$ invested capital \\
\hline ROA (Return on Assets) & (Net profit / average assets) 100 \\
\hline ROE (Return on Equity) & $\begin{array}{c}\text { (Net profit / average annual amount of } \\
\text { equity) } 100\end{array}$ \\
\hline \multicolumn{2}{|c|}{ The dynamics of change } \\
\hline Revenue from sales & Revenue $_{t}-$ Revenue $\left._{t-1}\right) 100 /$ Revenue $_{t-1}$ \\
\hline Gross value added & $\begin{array}{c}\text { (Value added }_{\mathrm{t}}-\text { Value } \text { added } \\
\mathrm{t}-1) 100 / \\
\text { Value added } \mathrm{a}_{\mathrm{t}-1}\end{array}$ \\
\hline
\end{tabular}

On the basis of grouped indicators, first of all, it is necessary to determine the synthetic indicator of economic and financial efficiency of the national economy of Ukraine in terms of the opportunities for the development of a particular industry that can be ensured by the TOPSIS (Technique for Order Preference by Similarity to an Ideal Solution) method $[14 ; 15]$ taking into account the following steps:

- definition of the hierarchical structure of the multicriteria problem of the levels of the national economy development;

- normalization of the values of economic and financial indicators;
- substantiation of criteria and features of financial and economic indicators on the basis of assigning weighting coefficients to them using the CRITIC (Criterion Importance Through Intercriteria Correlation) method [16];

- determination of the synthetic measures for economic and financial efficiency using the TOPSIS method.

- linear ordering of the national economy branches.

At the stage of formation of the hierarchical structure of the evaluation multicriteria task, the following elements are considered: the main criterion of evaluation, the subcriteria, features and objects of evaluation. The main criterion is positioned at the highest level of the hierarchy and contains several subcriteria (individual criteria contain features that describe the objects of evaluation) [15]. Peculiarities create features of development levels of objects, that is, branches of the national economy.

The choice of characteristics of the economic and financial state of the industries is based on objective and statistical analysis, and in order to exclude highly correlated features, the matrix analysis of the inverse correlation $R^{-1}$ is provided (in the case of excessive correlation of certain features relative to other features, the diagonal elements of the matrix $R^{-1}$ will exceed the unit that will be detected in bad numerical conditionality of the matrix $R$ [15].

The value $K$ of economic-financial characteristics for $N$ of statistical units (branches of economy), established on the basis of objective and statistical analysis, are summarized in the matrix of dimensional data $(N \times K)$ :

$$
X=\left(\begin{array}{cccc}
x_{11} & x_{11} & \ldots & x_{1 K} \\
x_{21} & x_{22} & \ldots & x_{2 K} \\
\ldots & \ldots & \ldots & \ldots \\
x_{N 1} & x_{N 2} & \ldots & x_{N K}
\end{array}\right),
$$

where $x_{i j}(i=1, \ldots, N),(j=1, \ldots, K)$ indicates the value of the $j$-th feature in the $i$-th statistical unit.

At the second stage, the normalization of functions is ensured in order to combine them into numeric ranges, and different approaches are used for that [15]. In our case, it is expedient to use the linear normalization approach - zeroed unitarization - by means of which one can compare the stimulator and the disintegrator on the basis of a single dimensionality using transformation formulas:

$$
\begin{aligned}
& z_{i j}=\frac{x_{i j}-\min \left\{x_{i j}\right\}}{\max \left\{x_{i j}\right\}-\min \left\{x_{i j}\right\}} \quad \text { (stimulator); } \\
& z_{i j}=\frac{\max \left\{x_{i j}\right\}-x_{i j}}{\max \left\{x_{i j}\right\}-\min \left\{x_{i j}\right\}} \quad \text { (destimulator); }
\end{aligned}
$$

Nominals:

$$
z_{i j}=\frac{x_{i j}-\min \left\{x_{i j}\right\}}{\operatorname{nom}\left\{x_{i j}\right\}-\min \left\{x_{i j}\right\}}, x_{i j} \leq \operatorname{nom}\left\{x_{i j}\right\}
$$




$$
z_{i j}=\frac{\max \left\{x_{i j}\right\}-x_{i j}}{\max \left\{x_{i j}\right\}-\operatorname{nom}\left\{x_{i j}\right\}}, x_{i j} \leq \operatorname{nom}\left\{x_{i j}\right\}
$$

Converted values of $z_{i j}$ features are normalized in the interval $\langle 0,1\rangle$.

The third stage is devoted to the formation of weighting coefficients for economic and financial indicators using the CRITIC method [16], presented in the form of $W=W_{1}, W_{2}, \ldots W_{K}$

Weighting factors in this specified method w. determined taking into account the standard deviation of each of the characteristics and coefficients of correlation between the features, and their vectority is as

$$
W_{j}=C_{j} / \sum_{k=1}^{K} C_{k}=1, j=1,2, \ldots, K
$$

follows:

$$
C_{j}=s_{j(z)} \sum_{k=1}^{K}\left(1-r_{j k}\right), j=1,2, \ldots, K
$$

where:

$S_{i(z)}$ - standard deviation, calculated for the normalized values of the $j$-th feature;

$r_{j k}-$ correlation coefficient between $j$-th and $k$-th features, for which $\sum_{j=1}^{K} w_{j}=1$.

In the future, the product of the normalized values of the features is determined by weight coefficients:

$$
z_{i j}^{*}=z_{i j} w_{i j}, i=1,2, \ldots, N, j=1,2, \ldots, K .
$$

At the fourth stage, we use a reference method for determining the value of the synthetic feature using the classical TOPSIS method for calculating the Euclidean distance to each object of the model:

- development

$$
z^{+}: z^{+}=\left(\max _{i}\left(z_{i 1}^{*}\right), \max _{i}\left(z_{i 2}^{*}\right), \ldots, \max _{i}\left(z_{i K}^{*}\right)\right)=\left(z_{1}^{+}, z_{1}^{+}, \ldots, z_{K}^{+}\right)
$$

- $\quad$ antidevelopment

$$
z^{-}: z^{-}=\left(\min _{i}\left(z_{i 1}^{*}\right), \min _{i}\left(z_{i 2}^{*}\right), \ldots, \min _{i}\left(z_{i K}^{*}\right)\right)=\left(z_{1}^{-}, z_{1}^{-}, \ldots, z_{K}^{-}\right)
$$

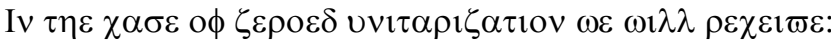

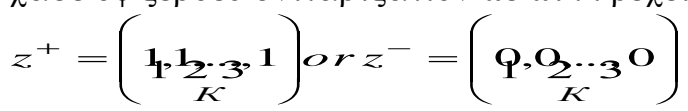

After defining an example of development and antidevelopment, the Euclidean distances of each unit of evaluation will be calculated as follows:

- development

$$
z^{+}: d_{i}^{+}=\sqrt{\sum_{j=1}^{K}\left(z_{i j}-z_{j}^{+}\right)^{2}}
$$

- antidevelopment

$$
z^{+}: d_{i}^{-}=\sqrt{\sum_{j=1}^{K}\left(z_{i j}-z_{j}^{-}\right)^{2}}
$$
$S_{i}$

The next step is to calculate the synthetic function value

$$
S_{i}=\frac{d_{i}^{-}}{d_{i}^{+}+d_{i}^{-}}, 0 \leq S_{i} \leq 1,(i=1,2, \ldots, N) .
$$

The smaller the distance of the desired unit from the developmental standard and, accordingly, farther from antidevelopment, the closer to 1 will be the significance of the synthetic function.

At the final stage, it is proposed to rank the branches of the national economy in accordance with the calculated synthetic values of economic and financial efficiency.

The multidimensional analysis of sub-sectors of the food industry sectors of Ukraine was carried out in accordance with the described methodology. In the State Classifier of Products and Services SC 016-2010 [17], the food industry is included in the section $\mathrm{C}$ (processing industry) and includes enterprises producing goods under codes 10 and 11.

Based on the data of the State Statistics Committee [18], the interim calculation of TOPSIS synthetic indicators for the food industry of Ukraine by the formed five groups (see Table 1) was carried out for 2 sub-periods: years of 2012 2014 and 2015-2017. Output results made it possible to specify seven groups of food producers that differ in terms of financial liquidity, debt load and maintenance, productivity, profitability, and dynamics of changes determined by intervals. The results of synthetic TOPSIS values and real values form separate clusters that are subject to cluster analysis. It was conducted taking into account individual concentrations (clusters) during the indicated periods. The results of cluster analysis are presented in Table 3 and 4.

Sub-sectors of the food industry belonging to the first cluster (10.11-10.13 - canned meat and meat products, 10.51 - dairy and cheese products, 11.07 - soft drinks, bottled mineral water, 11.01 - alcoholic beverages, distilled, 10.91 feed products for farm animals) have an average level of efficiency, which is confirmed by a general synthetic index with a value of 0.38 . In general, the indicators influencing its final value were characterized by higher (compared with the average in the industry) levels of liquidity and debt, but lower than the average industry profitability and yield. In general, the sub-sector of this cluster needs external sources of investment more than other enterprises of the food industry of Ukraine.

The cluster's fullness varied across different time segments by enterprises of various sub-sectors (during 20122014 - 10.11-10.13, 10.51, 11.07 and 11.01, during 20152017 - 10.11-10.13, 10.51, 10.91). The cluster 2 unites enterprises of sub-sectors with a high level of synthetic index - 0.43, which is affected by low debt levels and high profitability. Sub-sectors of this segment have a high level of return and are attractive both for domestic and foreign investment. 
TABLE II. UKRAINIAN FOOD INDUSTRY CLUSTERS ACCORDING TO THE RESALTS OF CALCULATION SYNTHETIC INDEXES

\begin{tabular}{|c|c|c|c|c|c|c|c|c|}
\hline \multirow{2}{*}{ Indicator } & \multicolumn{7}{|c|}{ Clusters } & \multirow{2}{*}{ Medium } \\
\hline & 1 & 2 & 3 & 4 & 5 & 6 & 7 & \\
\hline Current liquidity & 1.17 & 1.43 & 1.47 & 1.18 & 1.33 & 1.22 & 2.54 & 1.38 \\
\hline Instant liquidity & 0.85 & 0.97 & 0.93 & 0.65 & 0.73 & 0.89 & 1.71 & 0.9 \\
\hline Cash flow & 0.19 & 0.25 & 0.17 & 0.07 & 0.13 & 0.16 & 0.84 & 0.2 \\
\hline Synthetic, $S_{1}$ & 0.4 & 0.4 & 0.35 & 0.32 & 0.3 & 0.4 & 0.52 & 0.37 \\
\hline Total debt obligation & 0.55 & 0.44 & 0.44 & 0.64 & 0.58 & 0.48 & 0.3 & 0.5 \\
\hline Commitment by tangible assets & 4.14 & 6.36 & 5.77 & 4.47 & 3.95 & 6.04 & 15.05 & 5.66 \\
\hline Coverage of liabilities with financial surplus & 5.72 & 10.77 & 6.4 & 3.74 & 2.78 & 15.37 & 71.38 & 10.64 \\
\hline Coverage of interest with operating profit & 0.22 & 0.39 & 0.27 & 0.15 & 0.14 & 0.49 & 0.39 & 0.28 \\
\hline Synthetic, $S_{2}$ & 0.32 & 0.46 & 0.41 & 0.23 & 0.26 & 0.48 & 0.57 & 0.37 \\
\hline Total turnover of assets & 2.55 & 1.6 & 1.45 & 1.71 & 1.51 & 1.89 & 1.4 & 1.78 \\
\hline Productivity of operating assets & 0.46 & 0.54 & 0.41 & 0.31 & 0.28 & 0.74 & 0.54 & 0.45 \\
\hline Productivity of fixed assets & 0.82 & 0.92 & 0.82 & 0.71 & 0.72 & 1.28 & 1.1 & 0.88 \\
\hline Labor efficiency & 90.52 & 122.51 & 121.32 & 112.89 & 119.48 & 222.95 & 142.4 & 126.19 \\
\hline Synthetic, $S_{3}$ & 0.35 & 0.36 & 0.28 & 0.25 & 0.22 & 0.52 & 0.35 & 0.32 \\
\hline Operational & 3.31 & 8.04 & 5.62 & 4.06 & 3.45 & 9.84 & 5.94 & 5.56 \\
\hline Operating assets & 12.12 & 18.72 & 11.66 & 7.28 & 6.33 & 31.54 & 10.31 & 13.76 \\
\hline Invested capital & 5.25 & 9.96 & 6.32 & 3.72 & 2.63 & 15.34 & 6.92 & 6.91 \\
\hline ROA (Return on Assets) & 16.04 & 22.17 & 15.36 & 12.02 & 10.91 & 30.14 & 17.41 & 17.35 \\
\hline ROE (Return on Equity) & 13.10 & 19.32 & 12.0 & 10.65 & 7.38 & 31.21 & 13.92 & 14.86 \\
\hline Synthetic, $S_{4}$ & 0.39 & 0.55 & 0.41 & 0.35 & 0.32 & 0.71 & 0.44 & 0.44 \\
\hline Revenue from sales & 6.03 & 4.61 & 2.24 & 16.90 & -2.31 & 7.93 & -9.72 & 5.13 \\
\hline Gross value added & 7.06 & 4.34 & 6.61 & 15.16 & -3.23 & 6.25 & -9.48 & 5.03 \\
\hline Synthetic, $S_{5}$ & 0.43 & 0.43 & 0.44 & 0.51 & 0.37 & 0.43 & 0.31 & 0.43 \\
\hline The general synthetic indicator of the food industry & 0.38 & 0.43 & 0.37 & 0.33 & 0.3 & 0.5 & 0.43 & 0.37 \\
\hline
\end{tabular}

TABLE III. CLUSTER POSITIONING OF THE UKRAINIAN FOODS INDUSTRY SUBSECTORS IN 2012-2017

\begin{tabular}{|c|c|c|c|c|c|c|c|c|c|}
\hline \multirow{2}{*}{\multicolumn{2}{|c|}{$\begin{array}{c}\text { Years/ } \\
\text { clusters }\end{array}$}} & \multicolumn{8}{|c|}{ 2015-2017 } \\
\hline & & 1 & 2 & 3 & 4 & 5 & 6 & 7 & Total \\
\hline \multirow{8}{*}{ 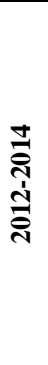 } & 1 & $\begin{array}{c}10.1,10.12 \\
10.13,10.51\end{array}$ & 11.07 & & & 11.01 & & & 6 \\
\hline & 2 & 10.91 & 10.72 & 10.89 & & & $10.52,10.71$ & & 5 \\
\hline & 3 & & $\begin{array}{l}10.86 \\
10.73\end{array}$ & $\begin{array}{c}10.61,10.82 \\
10.83\end{array}$ & & & & 10.42 & 6 \\
\hline & 4 & & & & $\begin{array}{c}10.20,10.41 \\
10.85\end{array}$ & 10.39 & & & 4 \\
\hline & 5 & & 10.81 & 11.02 & & $10.32,11.03$ & & & 4 \\
\hline & 6 & & & & & & $10.84,11.05$ & & 2 \\
\hline & 7 & & & & & & & 10.31 & 1 \\
\hline & Total & 5 & 5 & 5 & 3 & 4 & 4 & 2 & 28 \\
\hline
\end{tabular}

However, the subfield format has changed somewhat during the study period. In 2012-2014 it consisted of: $10.91-$ food products for livestock, 10.71 - 10.72 - low-moisture bakery products and flour confectionery products, of longterm and short-term storage, 10.89 - other foodstuffs, 10.52 - ice cream. During the years of 2015-2017: 11.07 - soft drinks, bottled mineral water, 10.72 - bakery products, low humidity, confectionery, flour, long-term storage, 10.73 macaroni, noodles, couscous and similar flour products, 10.81 - sugar.

The cluster group 3 is coherent in its overall level of synthetic indicator of financial and economic efficiency to cluster number $1(0.38)$, but the components of such a result differ by the lower level of indicators of liquidity and debt servicing. At the same time, this cluster is characterized by an average level of profitability and a high level of growth in sales and value added, which forms attractive prospects for long-term investment in this direction of food production. The unchanging core of the group consists of the following enterprises: 10.61 - products of the milling industry, 10.82 - cocoa products, chocolate and sugar confectionery, 10.89 - tea and coffee, processed. During the period of 2012-2014, the group 10.86 was updated with ready-made food products homogenized for children's and dietary foods, 10.73 - macaroni, noodles, couscous and similar flour products, 10.42 - margarine and similar edible fats, and in 2015-2017 they were changed in the sub-sector 10.89 with other food products, 11.02 - grape wines.

The cluster group number 4 combines enterprises with a low level of total synthetic index (0.33) - low liquidity, profitability and high level of indebtedness compared to other branches of the food industry. However, these subsectors show a high positive dynamics of sales volumes and value added. This points to their investment attractiveness but not only in increasing their production capacity, but also in their technological upgrading, which will increase their operating profitability or cost-competitiveness. Invariably the group during 2012-2017 includes: 10.20 - fish, crustaceans and shellfish products, processed and preserved, 10.41 - oils and fats, 10.85 - food sets and prepared meals. 
The cluster number 5 is characterized by the lowest level of synthetic indicator in the food industry $(0.3)$, which is determined by the lowest rates of practically all components of financial and economic efficiency. To this group in 20122014 enterprises included 4 sub-sectors: 10.81 - sugar, 11.02 - grape wines, 10.32 - fruit and vegetable juices, 11.03 cider and other fruit wines. In 2015-2017, positions 10.32 and 11.03 remained. The listed sub-sectors require significant investments, and in their economic nature they are complex and unattractive for both domestic and foreign investors.

The highest level of efficiency, as well as investment attractiveness is characterized by the sixth group, to which during the years of 2012-2017 the following sub-sectors of the food industry were included: 10.84 - condiments and spices, 11.05 - beer. The total synthetic rate in the group is 0.5 .

The cluster number 7 during the analyzed period was characterized by a general synthetic efficiency indicator of 0.43 , which in general exceeds the average in the food industry as a whole. However, despite the rather high financial liquidity and low level of indebtedness of the enterprise, the sub-sectors of this cluster practically did not show a positive dynamics in the scopes of sales of goods and value added, that is, they were not attractive for investment. During 2012-2017, this group included a sub-sector of 10.31 - potatoes, processed and preserved, and also during 20152017 there was included a sub-sector 10.42 - margarine and similar edible fats.

\section{CONCLUSIONS AND OUTLOOKS}

The definition of investment priorities for the development of the national economy of Ukraine is to identify sectors that, in the strategic perspective, can provide a high level of added value in creating consumer values. Among them, the food industry occupies an important place, which can significantly increase the total value added, using the potential of agricultural production. However, it covers various consumer-oriented and technological facilities of the sub-group, which determines their various financial and economic outcomes of activity, and therefore means different investment prospects. TOPSIS and CRITIC methods were used to assess the investment priorities of industry development.

The obtained results allowed differentiating the food industry into groups with wide possibilities for analysis, on the basis of which their attractiveness for investment was determined. According to the calculations of synthetic indicators and cluster analysis, it was determined that the most priority investment plans for the period include meat processing, oil fat, fish processing, confectionery, milling branch and cereals, a subsector for the production of food sets and ready-made dishes. The development of these subsectors is economically profitable both from the standpoint of the owners of capital and from the point of view of the public interest, since it will ensure the growth of the value added within the national economy.

Therefore, when forming a state economic policy it is expedient to differentiate approaches to creation of investment preferences for attraction of strategic investors. In particular, such preferences should be defined for the development of the food industry in the context of those subsectors that correspond to the dynamics of food markets in Ukraine and increase the opportunities for entry into the European Union market.

\section{ACKNOWLEDGMENT}

The work was carried out within the State budget project "Modeling financial and economic security of businesses in their innovative development strategies", project's registration number $0117 \mathrm{U} 001170$.

\section{REFERENCES}

[1] Global economic development: trends, asymmetries, regulation: monograph: under scientific edit. D. Lukianenko, A. Poruchnyk, V. Kolesov, Kyiv : KNEU, 2013.

[2] O. E. Bavyko, and M. P. Petrenko, "Management of structural restructuring of the economy in the conditions of post-industrial transformations", Effective Economy, no 12, 2014. [Online]. Available: http://www.economy.nayka.com.ua/?op=1\&z=360.

[3] S. Radziyevska, "Global economic processes and Ukraine", International Economic Policy, no 1 (20), pp. 80-104, 2014.

[4] V. P. Reshetylo, and I. P. Ostrovskyi, "Economic globalization and contradictions in the structural policy of the state". Effective Economy, no 6, 2016. [Online]. - Available: http://www.economy.nayka.com.ua/ ?op=1\&z=5055.

[5] "New Global Partnership: Eradicate Poverty and Transform Economies Through Sustainable Development. Report of the High_Level Panel of Eminent Persons on the Post-2015 Development Agenda", New York: United Nations Publications, 2013.

[6] Vancur, and Olson, "Autocracy, Democracy and Prosperity", in Strategy and Choice, Richard J. and Zeckhauser, Eds. Cambridge, MIT Press, 1991, pp.131-157.

[7] J.Y. Lin, New Structural Economics: A Framework for Rethinking Development and Policy, Washington : World Bank Publications, 2012.

[8] M. Porter, On Competition. Moscov : Willjams, 2005.

[9] J.E.Stiglitz, J. Esteban, and J.Y. Lin, The Industrial Policy Revolution I: The Role of Government Beyond Ideology, New York: Palgrave Macmillan, 2013.

[10] I. Wallerstein, The Modern World-System, Moscov: University of Dmitriy Pozarskiy, 2016.

[11] V. V. Stadnyk, and V.O. Mukomela-Mychalez, "Entrepreneurial structures of the industrial sector of the economy of Ukraine: status and prospects of development in the conditions of globalization", Herald of Khmelnytskyi National University. Economic Sciences, no 4, pp. 93-99, 2017.

[12] Capital investments by the type of industrial activity, 2018. [Online]. Available: http://www.ukrstat.gov.ua.

[13] V. Stadnyk, P. Izhevskiy, O. Zamazii, A. Goncharuk and O. Melnichuk "Factors of enterprises' strategic selection of participation forms in integration formations", Problems and Perspectives in Management, no 16 (2), pp. 90-101, 2018. Doi.org/10.21511/ppm.16(2).2018.09.

[14] R. Rahim, A. P. Utama Siahaan, and R. F. Wijaya "Technique for Order of Preference by Similarity to Ideal Solution (TOPSIS) Method for Decision Support System in Top Management”. International Journal of Engineering \& Technology, no 3-4, pp. 290-293, 2018.

[15] T.Miranda Lakshmi, and V. Prasanna Venkatesan, "A Comparison of Various Normalization in Techniques for Order Performance by Similarity to Ideal Solution (TOPSIS)", International Journal of Computing Algorithm, no 3, pp. 255-259, 2014.

[16] E. A. Adali, A. and T. Is1k, "Critic and Maut Methods for the Contract Manufacturer Selection Problem", European Journal of Multidisciplinary Studies, no 2 (5), pp. 93-10, 2017.

[17] State Classifier of Products and Services SC 016-2010 [Online]. Available: https://dkpp.rv.ua/.

[18] State Statistics Service of Ukraine. Activity of enterprises. [Online]. Available: http://www.ukrstat.gov.ua. 